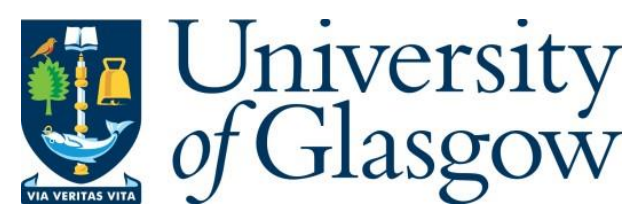

Anker, T. B. (2017) Globally European: reflections on EMJ from the incoming Editorin-Chief. European Management Journal, 35(2), pp. 141-144.

There may be differences between this version and the published version. You are advised to consult the publisher's version if you wish to cite from it.

http://eprints.gla.ac.uk/135263/

Deposited on: 15 March 2017

Enlighten - Research publications by members of the University of Glasgow

http://eprints.gla.ac.uk 


\section{Globally European: Reflections on EMJ from the incoming Editor- in-Chief}

\section{Our journey}

Since the European Management Journal (EM)) came hot off the press for the first time back in 1982, the Journal has undergone tremendous development. We started out with a business letter format and a very strong practitioner focus that developed gradually into a broad-based flagship management journal, publishing internationally leading scholarly papers.

This journey is evidenced by three key stats. First, we have grown in terms of submissions and received no less than 833 new papers in 2016, roughly 16 new submissions each week. Second, we are a highly selective management journal with an acceptance rate of $9.4 \%$ in 2016 , desk rejecting $70.2 \%$ of all new submissions. Third, this means that we are publishing only the best management scholarship in Europe and beyond, which is reflected in our growing impact factor, now sitting at 1.437 (see Table 1).

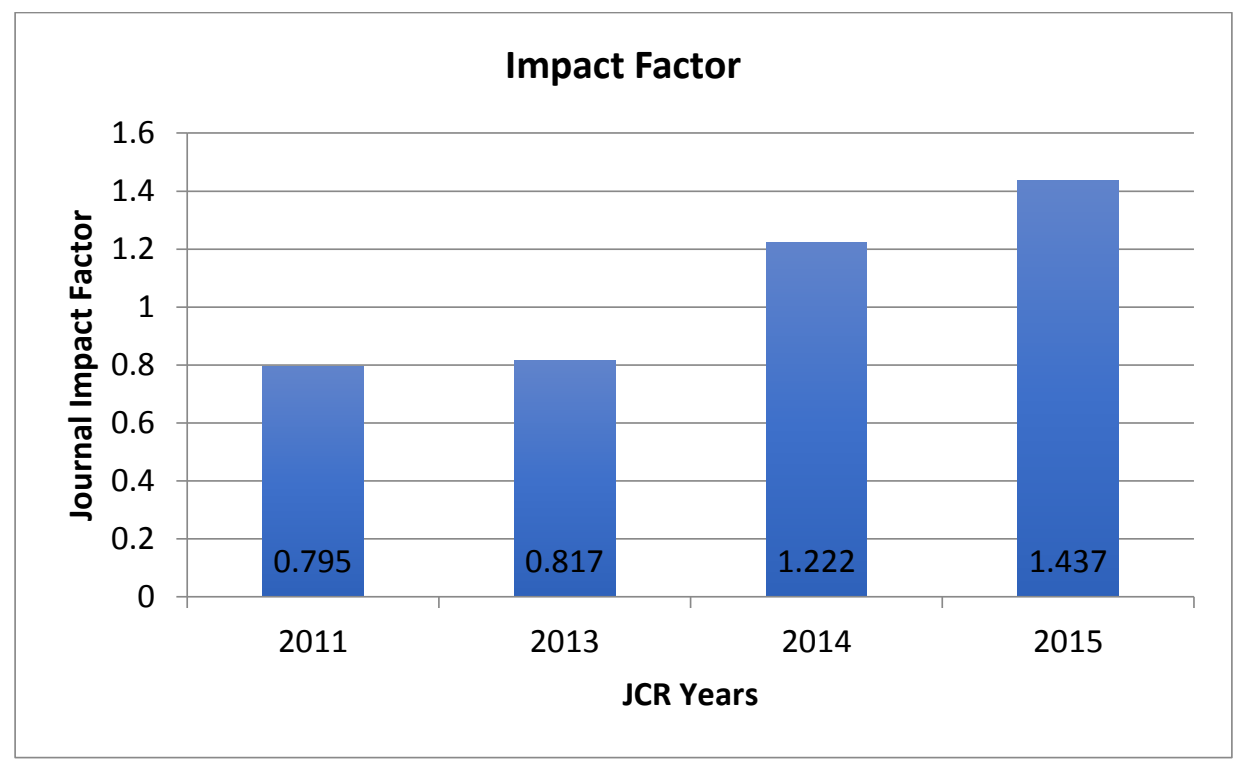

Table 1: Overview of increase in EMJ impact factor from 2011-2015.

This highly positive development of the journal is in no small part due the devotion and effort of Michael Haenlein, Editor-in-Chief from 2012 to 2015, and Sabina Siebert, Editor-in-Chief from 2015 to 2017. It is with a feeling of honour and, I have to say, some trepidation that I now take over as Editor-in-Chief. My main task is not to change the 
Journal, but to sustain the trajectory of scholarly growth which Michael and Sabina have created with such brilliance.

Most journal ranking lists classify EMJas a 2* outlet. However, our clear ambition is to establish $E M J$ as a solid $3^{*}$ journal within the foreseeable future. We believe this is a highly viable and credible aspiration. Our impact factor is now higher than a number of journals ranked $3^{*}$ on the influential ABS/AJG ranking list. And our desk rejection and acceptance rates clearly evidence $E M J$ to be a highly discerning journal publishing nothing but the best European scholarship.

\section{Reflections on Europe}

We as a journal have changed. And so has Europe. It is safe to say that the EU is currently finding itself in a period of upheaval: the UK's decision to leave the EU is not just a matter of domestic politics, it is a seismic movement that questions the very foundation of what it is and means to do business in Europe (Anker, 2017). Many of the strongest political narratives unfolding across not just Europe but most liberal democracies are fuelled by patriotism and protectionism, with core ideological messages worryingly situated at the wrong side of the distinction between civic and non-civic nationalism.

Not surprisingly, management scholars have responded to the increased politicization. One concrete expression of this is the cotemporary focus on businesses as political actors, engaging in activities such as peace-making, corporate diplomacy, protection of human rights and democratic nation-building (see e.g. Anker, 2017; Rasche 2015; Scherer \& Palazzo 2011; Scherer, Palazzo \& Matten 2014; Scherer et al. 2016; Westermann-Behaylo, Rehbein \& Fort, 2015). Corporations and organizations now engage in types of agency that were previously falling within the exclusive remit of state actors (Scherer \& Palazzo 2011). An upcoming EMJ special issue focuses on this changing role of businesses in the intersection between commercial profit maximization, corporate governance and democracy. ${ }^{1}$

The EMJ series, Reflections on Europe, was launched by Michael Haenlein and Sabina Siebert to address three core questions (Haenlein and Siebert 2014). First, what is European management in general, and how does it differ from other management styles in the world? Second, is and should there be a distinctive approach to management research in Europe? Third, how should European-based journals position themselves in the world of academic research, so that they can compete with North American journals but at the same time offer something different?

These questions still lie at the heart of the Reflections on Europe series, but, with the unfolding politicization of business in Europe and across Western liberal democracies, another pressing question should be added to the list: How can and should businesses respond to the growing nationalism, isolationism and anti-globalization across liberal democracies? EMJ welcomes contributions on this topic and will invite

\footnotetext{
${ }^{1}$ EMJ will soon be calling for contributions to a special issue entitled 'Governing complexity to challenge neo-liberalism? New democracy, new corporations, new markets'. The special issue will be guest-edited by Thomas Clarke, University of Technology, Sydney, and Wafa Khlif, Toulouse Business School, Barcelona.
} 
Reflections on Europe to address the fundamental question of what it means to be a European business operating in a political climate governed by radical uncertainty.

\section{$E M J$ - As global as its readers and authors}

$E M J$ is a truly global journal. Despite its natural focus on the European business and management context, it is a journal with a genuinely international outlook. This is reflected in not only the range of topics covered in our published articles, but also the geographical breakdown of corresponding authors and readership. While the majority of corresponding authors are based in Europe, the number from the USA, Canada, Australia, and the Middle East is steadily and significantly increasing (see Table 2). Authorship from Asian countries has decreased, but, given the strong investment in science and technology across the region, the number of Asian authors published in EMJ is likely to increase over the coming years. This impression is further substantiated by the quantity of Asian readers, with China alone accounting for $5.6 \%$ of downloaded articles in 2016.

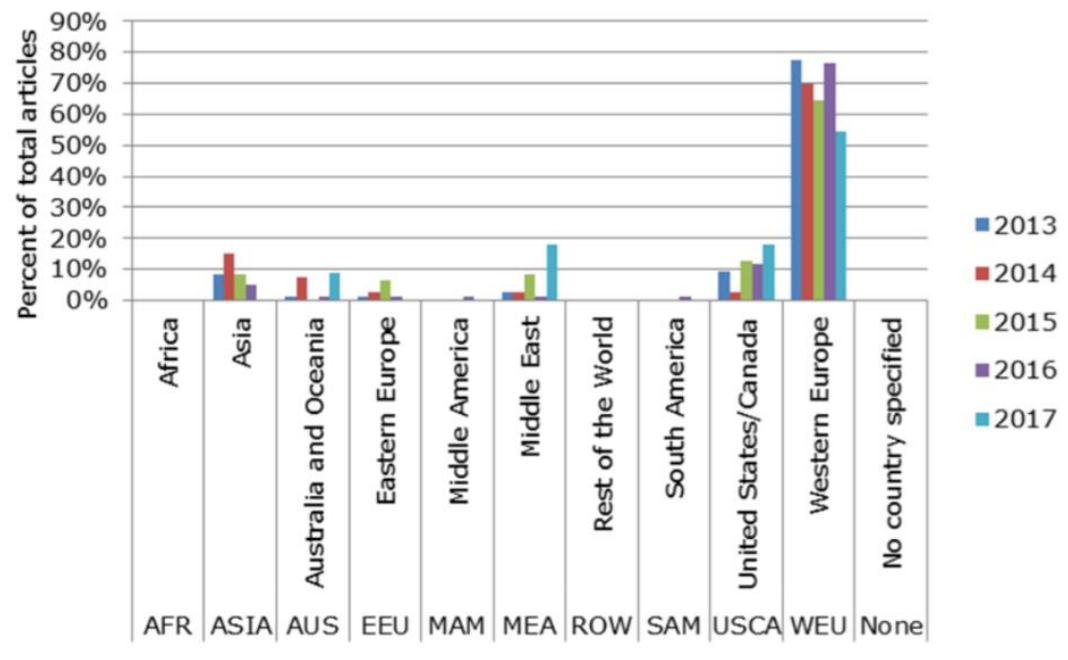

Table 2. Geographical breakdown of EMJ corresponding authors.

EMJ readers include a global audience of scholars, policy makers and business professionals. In terms of usage statistics, the three countries with the most downloaded articles in 2016 are the UK (26.3\%), Australia (9.1\%) and the USA (7.6\%), closely followed by Germany (6.1\%) and China (5.6\%) (see Table 3 below). ${ }^{2}$ Figure 1 provides a graphical representation of the geography of our readership for the past five years.

\begin{tabular}{|l|c|c|}
\hline & $\begin{array}{c}\text { Usage 2016 measured in } \\
\text { downloaded articles }\end{array}$ & Usage in percentage \\
\hline
\end{tabular}

\footnotetext{
${ }^{2}$ EMJ also has a very strong representation in Scandinavia (Denmark, Norway, Sweden, Finland and Iceland), accounting for $6.8 \%$ of total usage in 2016.
} 


\begin{tabular}{|l|c|c|}
\hline UK & 148208 & $26.5 \%$ \\
\hline Australia & 50916 & $9.1 \%$ \\
\hline USA & 42279 & $7.6 \%$ \\
\hline Germany & 33902 & $6.1 \%$ \\
\hline China & 31035 & $5.6 \%$ \\
\hline
\end{tabular}

Table 3. Usage per top countries.

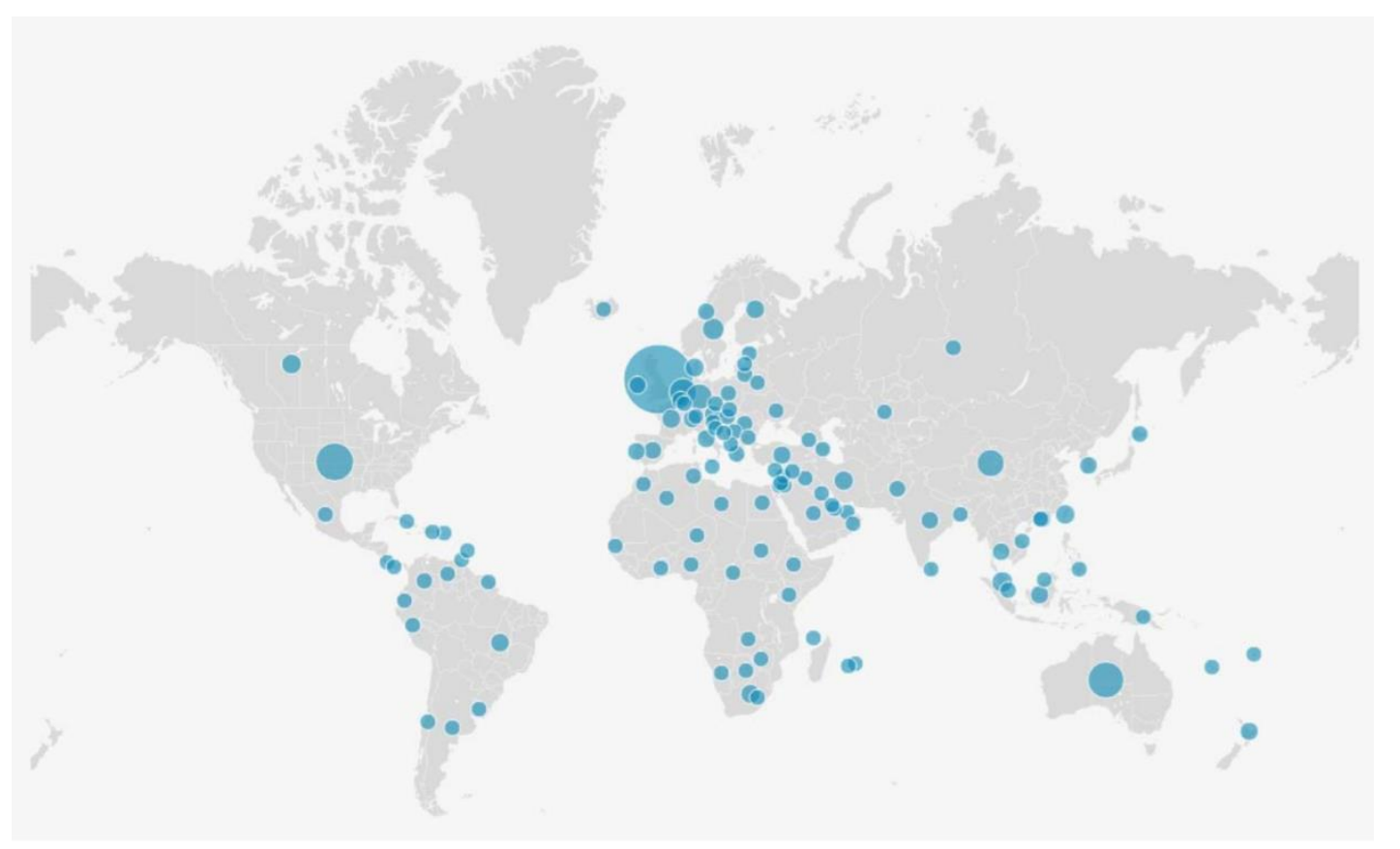

Figure 1. Graphic representation of EMJ readership globally.

\section{Novelty}

EMJ has always been publishing innovative research, which challenges the status quo. This explains why the majority of submissions that we desk reject fall into the category of 'lack of contribution'. EMJ is specifically looking for papers that make innovative contributions across three main criteria: novelty, epistemic impact and theoretical advancement.

First, many high quality papers do not make the cut simply because the research question lacks novelty. The research is rigorous, well-written and coherent, but the contribution to the advancement of new knowledge is too incremental. We encourage authors to take calculated risks when choosing their research questions, allowing freedom to discover new contexts or explore established domains in new ways. One such example is Chia's (2014) Reflection on Europe, which argues that management scholarship should aspire to an ideal of artistic rather than technical rigour in order to achieve flying leaps of imagination. In Chia's view, such a philosophical approach will eventually have greater influence on management practice as it will shape the mind-set of business people rather than providing new technocratic knowledge. There is, of 
course, profound disagreement on this issue. But agreement or disagreement is beside the point. What Chia does well is identifying a novel and thought-provoking perspective on a foundational construct of relevance to all management scholars (i.e. scientific rigour), and it is this approach of framing an interesting research question within an established or new research domain that is key to novelty.

Second, a good deal of papers submitted to EMJare desk rejected because their contributions are too narrow. We are not a specialist journal but a general management outlet, meaning that all intellectual contributions have to speak to the intellectual curiosity of management scholars from a broad range of backgrounds. As such, we are particularly looking for contributions that have epistemic impact across disciplinary boundaries within the broad domain of management. A paradigm of this is our most cited paper by Gebaur, Worch and Truffer (2012). As the abstract explains, the paper "focuses on absorptive capacity in the context of strategic innovation" $(2012,59)$ and it is precisely this focus on a general context of study that all scholars and professionals can easily relate to that transforms the paper from providing a specialist, incremental contribution into being a genuinely innovative paper with cross-reaching epistemic impact.

Third, a key trend in top scholarly management journals is an increasingly strong focus on theoretical contributions. EMJ is no exception. The ideal paper (if there is such a thing) provides an empirically grounded theoretical innovation: it has a thorough empirical component and manages to either use theory to interpret and contextualize data to clarify the uniqueness, reach and significance of the study, or it introduces new concepts and theoretical frameworks informed by empirical research. As our previous Editor-in-Chief, Michael Haenlein (2015, p. 159), puts it: "The generalizability of a study's findings usually comes from the theory, not the data."

A commanding example is our recently published paper by Giustiniano, Pina e Cunha and Clegg (2016), which introduces for the first time the concept of zemblanity to organization studies. Zemblanity denotes the social construction of actions intended to evade security systems and risk management protocols (Giustiniano, Pina e Cunha and Clegg, 2016). As such, it is a counterpart concept to the well-established notion of organizational serendipity. The authors use the empirical case of the Costa Concordia disaster in which 32 people drowned to meticulously motivate, explain and define the concept of zemblanity. The paper is an outstanding example of scholarly innovation in that it introduces a new theoretical concept with both epistemic and practical impact in organizational behaviour, while continuously stimulating intellectual curiosity by grounding the theoretical contribution in a real-life case, which makes the paper a scholarly page-turner.

On behalf of $E M$ J, I would like to encourage you to submit your most innovative and rigorous work to the Journal. 


\section{References}

Anker, T. B. (2017). Corporate democratic nation-building: Reflections on the constructive role of businesses in fostering global democracy. European Management Journal, 35(1), 1-7. DOI: 10.1016/j.emj.2016.12.003

Chia, R. (2014). Reflections on the distinctiveness of European management scholarship. European Management Journal, 32(5), 683-688. DOI: 10.1016/j.emj.2014.06.002

Gebauer, H., Worch, H., \& Truffer, B. (2012). Absorptive capacity, learning processes and combinative capabilities as determinants of strategyic innovation. European Management Journal, 30(1), 57-73. DOI: 10.1016/j.emj.2011.10.004

Giustiniano, L., Pina e Cunha, M. \& Clegg, S. (2016). Organizational zemblanity. European Management Journal, 34(1): 7-21. DOI: 10.1016/j.emj.2015.12.001

Haenlein, M. (2015). From the outgoing editor: Where have all the papers gone? Goodbye, EMJ! European Management Journal, 33(X), 157-159. DOI: 10.1016/j.emj.2015.03.006

Haenlein, M. \& Siebert, S. (2014). Reflections on Europe: Introduction to the Series. European Management Journal, https://www.journals.elsevier.com/europeanmanagement-journal/reflections-on-europe-introduction-to-the-series.

Rasche, A. (2015). The corporation as a political actor - European and North American perspectives. European Management Journal, 33(1), 4-8. DOI: 10.1016/j.emj.2014.08.001

Scherer, A. G., \& Palazzo, G. (2011). The new political role of business in a globalized world: A review of a new perspective on CSR and its implications for the firm, governance, and democracy. Journal of Management Studies, 48(4), 899-931. DOI: $10.1111 / \mathrm{j} .1467-6486.2010 .00950 . \mathrm{x}$

Scherer, A. G., Palazzo, G., \& Matten, D. (2014). The business firm as a political actor: A new theory of the firm for a globalized world. Business \& Society, 53(2), 143156. DOI: $10.1177 / 0007650313511778$

Scherer, A. G., Georg, A., Rasche, A., Palazzo, G., \& Spicer, A. (2016). Managing for Political Corporate Social Responsibility: New Challenges and Directions for PCSR 2.0. Journal of Management Studies, 53(3). 273-298. DOI: 10.1111/joms.12203

Westermann-Behaylo, M. K., Rehbein, K., \& Fort, T. (2015). Enhancing the concept of corporate diplomacy: Encompassing political corporate social responsibility, international relations, and peace through commerce. Academy of Management Perspectives, 29(4), 387-404. DOI: 10.5465/amp.2013.0133 